Utah State University

DigitalCommons@USU

\title{
The Influence of Photoperiod on the Flight Activity of Honeybees
}

\author{
J. A. Kefuss \\ William P. Nye \\ Utah State University
}

Follow this and additional works at: https://digitalcommons.usu.edu/piru_pubs

Part of the Entomology Commons

\section{Recommended Citation}

Kefuss, J. A., and W. P. Nye. 1970. The Influence of Photoperiod on the Flight Activity of Honeybees. J. Apic. Res. 9(3):133-139, gigs., tables.

This Article is brought to you for free and open access by the Pollinating Insects Research Unit at DigitalCommons@USU. It has been accepted for inclusion in All PIRU Publications by an authorized administrator of DigitalCommons@USU. For more information, please contact digitalcommons@usu.edu.

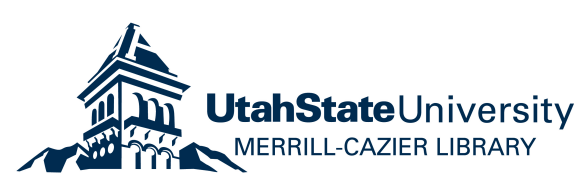


U. S. DEPAR ASEO BY
FOR OFFIGIAL USE

Journal of Apicultural Research 9(3) : 133-139 (1970)

\title{
THE INFLUENCE OF PHOTOPERIOD ON THE FLIGHT ACTIVITY OF HONEYBEES*
}

\author{
J. A. Kefuss $\nmid$ And W. P. NYE \\ Entomology Research Division, Agricultural Research Service, U.S.D.A., Logan, \\ Utah 84321, U.S.A.
}

Manuscript received for publication 19th August 1969

\section{Summary}

Honeybees in controlled-environment rooms developed flight activity patterns in response to the cycles of light and dark. As the photophase was lengthened, flight activity per unit time decreased, and in continuous light the diurnal rhythm faded. By altering the timing of the photophase, bees could be conditioned to high flight activity at times other than their "normal" peak flight period in the afternoon.

\section{Introduction}

One of the more exciting areas of current research concerning honeybees (Apis mellifera) is concerned with flight rhythms. Thus, Soczek (1958) observed that queens had a peak of flight activity between 14.45 and $15.15 \mathrm{hr}$, and Howell and Usinger (1933), Kurennoi (1954) and Oertel (1966) found that maximum flight of drones occurred between 14.00 and $17.00 \mathrm{hr}$. However, Taber (1964) pointed out that peak flight of drones may shift during the season, and advanced the hypothesis that "as the season progresses with days becoming longer and temperatures higher, the drones fly later in the day and their flight is more concentrated."

Flight rhythms of worker bees have been studied from the tropics to the Arctic Circle, and these investigations have shown that outdoor flight activity is correlated with nectar flow, pollen collection, temperature, and weather (Butler \& Finney, 1942; Domagala-Lipińska, 1962; Gary, 1967; Hocking \& Sharplin, 1964; Kenyon, 1898; Lundie, 1925; Sekiguchi \& Sakagami, 1966; Smith, 1953). Moreover, flight activity indoors was found to be correlated with the collection of sugar syrup and the temperature of the flight rooms (Bennet \& Renner, 1963; Nelson, 1964).

In view of these data, the questions we attempted to answer at the Wild Bee Pollination Investigations Laboratory included the following: What would happen if honeybees were maintained with such nearly constant environmental conditions that they could always fly, but had no need to forage for their food supplies? Would the bees remain in their hives, or would a flight rhythm develop? If a rhythm developed, what form would it take? Would variations in the photophase result in a shift in the peak of flight activity?

\footnotetext{
* In co-operation with Utah Agricultural Experiment Station

$\uparrow$ Present address: Institut für Bienenkunde (Polytechnische Gesellschaft), 637 Oberursel/Taunus, Im Rosengärtchen, W. Germany
}

The use of trade names in this paper does not imply the U.S. Department of Agriculture's endorsement of the equipment mentioned. 


\section{Methods and Materials}

Eight glass-walled observation hives, each with 4 shallow Langstroth frames $(13.7 \times$ $44.8 \mathrm{~cm}$ ) one above the other, and with equal amounts of bees (covering at least 2 frames), brood (a mean of 413 capped cells per colony), and empty comb were used. Four were placed in each of two controlled-environment rooms (temperature $30 \pm 3^{\circ} \mathrm{C}$ and relative humidity $30 \pm 5 \%$ ) on 5th July, 1966. These rooms were constructed by partitioning the chamber described by Nye (1962). The honeybees used were commercial Italian hybrids (Apis mellifera ligustica). Sister queens were instrumentally inseminated with sperm from the same drone line, to reduce potential behavioural differences that could arise from genetic variability; they were introduced to the colonies on 6th July. To prevent stimulation of flight by the necessity to forage, pollen was provided for each colony in a small tray set on top of the uppermost frame, and sugar syrup and water were given in glass jars on top of the hives. All colonies were allowed unrestricted flight within their flight-rooms.

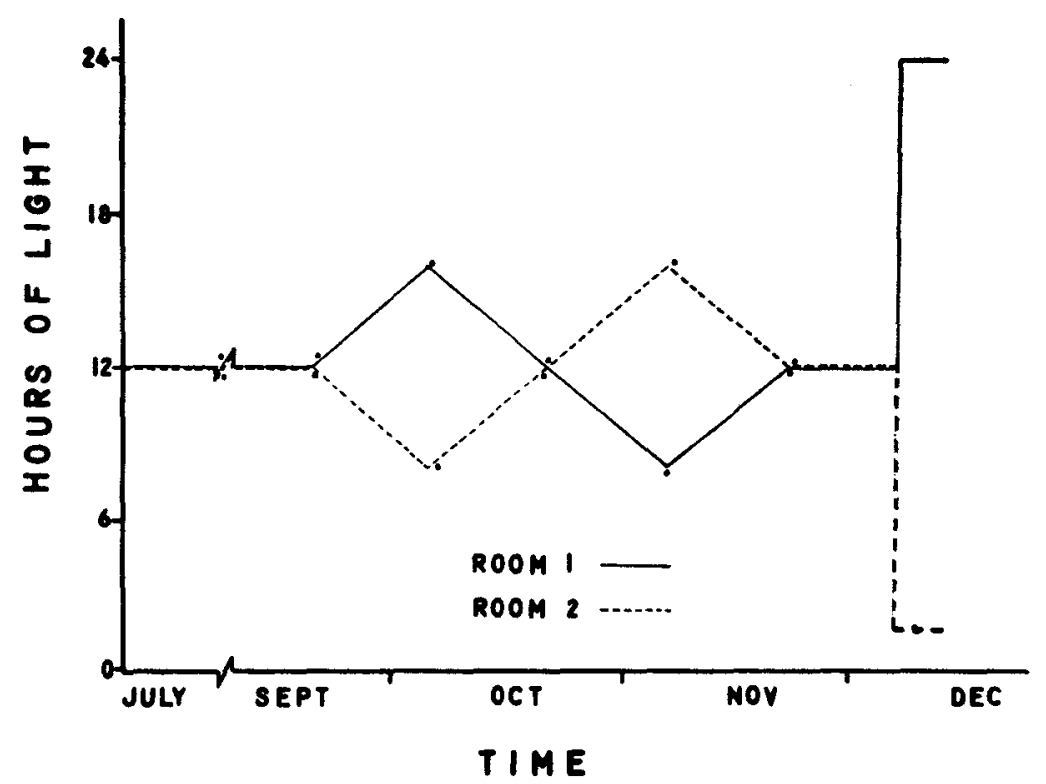

FIG. 1. Diurnal light cycles used in 1966. Dots indicate when flight activity was photographed.

The rooms were maintained with a 12-hour light (L) and 12-hour dark (D) period each day from 5 th July until 20th September 1966, when the photophase was lengthened (room 1) or shortened (room 2) by 15 minutes per day until photophases of 8,12 or 16 hours a day were reached; the details are shown in Fig. 1. We had found during an 8-month test in 1965 that the number of flights per unit time increased when the photophase was shortened, and decreased when it was lengthened; so we put the present observations on a quantitative basis at the end of the 1966 test, by maintaining room 1 with continuous light for $5 \frac{1}{2}$ days and room 2 with a $L: D$ cycle of $2: 22$ hours for 6 days, starting on 8th December and ending on 13th December 1966 . During this period all the colonies were broodless and therefore no new bees entered the populations. On selected days flight activity through one area $(4.6 \times 2.4 \mathrm{~m})$ of each room 
was recorded at 30 -second intervals during the photophase period, by time-lapse photography, using a Bolex $\mathrm{H} 16$ cine camera (10-mm wide-angle lens) actuated by a Stevens cine timer (Table 1). The number of bees in every thirtieth photograph (every 15 minutes) was then counted twice by each of two technicians, and the mean of these four counts was taken.

TABLE 1. Details of light : dark $(L: D)$ cycles on dates when counts were made.

\begin{tabular}{|c|c|c|c|}
\hline \multicolumn{2}{|c|}{ Date } & \multicolumn{2}{|c|}{ LD cycle $(\mathrm{hr}, \mathrm{min})$} \\
\hline Room 1 & Room 2 & Room 1 & Room 2 \\
\hline Aug. 27 & Aug. 28 & LD $12.00: 12.00$ & LD $12.00: 12.00$ \\
\hline Sep. 22 & Sep. 21 & LD $12.45: 11.15$ & LD $11.45: 12.15$ \\
\hline Oct. 6 & Oct. 7 & LD $16.00: 8.00$ & LD $8.15: 15.45$ \\
\hline Oct. 21 & Oct. 20 & LD $12.00: 12.00$ & LD $11.45: 12.15$ \\
\hline Nov. 6 & Nov. 7 & LD $8.15: 15.45$ & LD 16.00: 8.00 \\
\hline Nov. 22 & Nov. 23 & LD $12.00: 12.00$ & LD $12.00: 12.00$ \\
\hline Dec. 8 & Dec. 7 & LL) & LD $12.00: 12.00$ \\
\hline Dec. 9 & - & LL & - \\
\hline Dec. 10 & - & LL $\left.\right|_{\text {continuous }}$ & - \\
\hline Dec. 11 & - & LL Continuous & - \\
\hline Dec. 12 & - & LL $\left.\right|^{\text {1Ignt }}$ & - \\
\hline $\begin{array}{l}\text { Dec. } 13 \\
\text { (morning) }\end{array}$ & Dec. 13 & LL & LD $2.00: 22.00$ \\
\hline
\end{tabular}

\section{Results and Discussion}

The flight patterns observed when the $L: D$ cycles were $8: 16,12: 12$, and $16: 8$ hours are shown in Fig. 2 . With the $8: 16$ hour cycle, the first quarter of the photophase ( 2 hours) was characterized by restricted flight, the second quarter by sharply increasing flight, and the third and fourth quarters by maximum flight followed by a rapid final decrease. With the $12: 12$ and $16: 8$ hour cycles the initial restricted flight period was longer (first half of photophase), the increasing flight activity occurred during the third quarter, and the final decrease occupied the fourth quarter of the photophase. The flight activity during the second half of the photophase was greater than during the first half, for all three photoperiods (Table 2). Maximum flight always occurred between 14.00 and $16.00 \mathrm{hr}$, and the differences between the time of peak flight in the different photoperiods were not statistically significant.

TABLE 2. Ratio between flight activity during the first and second halves of the photophase, for the three photophases shown in Fig. 2.

\begin{tabular}{cc}
\hline Light-dark cycle (hr) & Ratio \\
\hline $8: 16$ & $1: 2 \cdot 6$ \\
$12: 12$ & $1: 4 \cdot 4$ \\
$16: 8$ & $1: 5 \cdot 3$
\end{tabular}




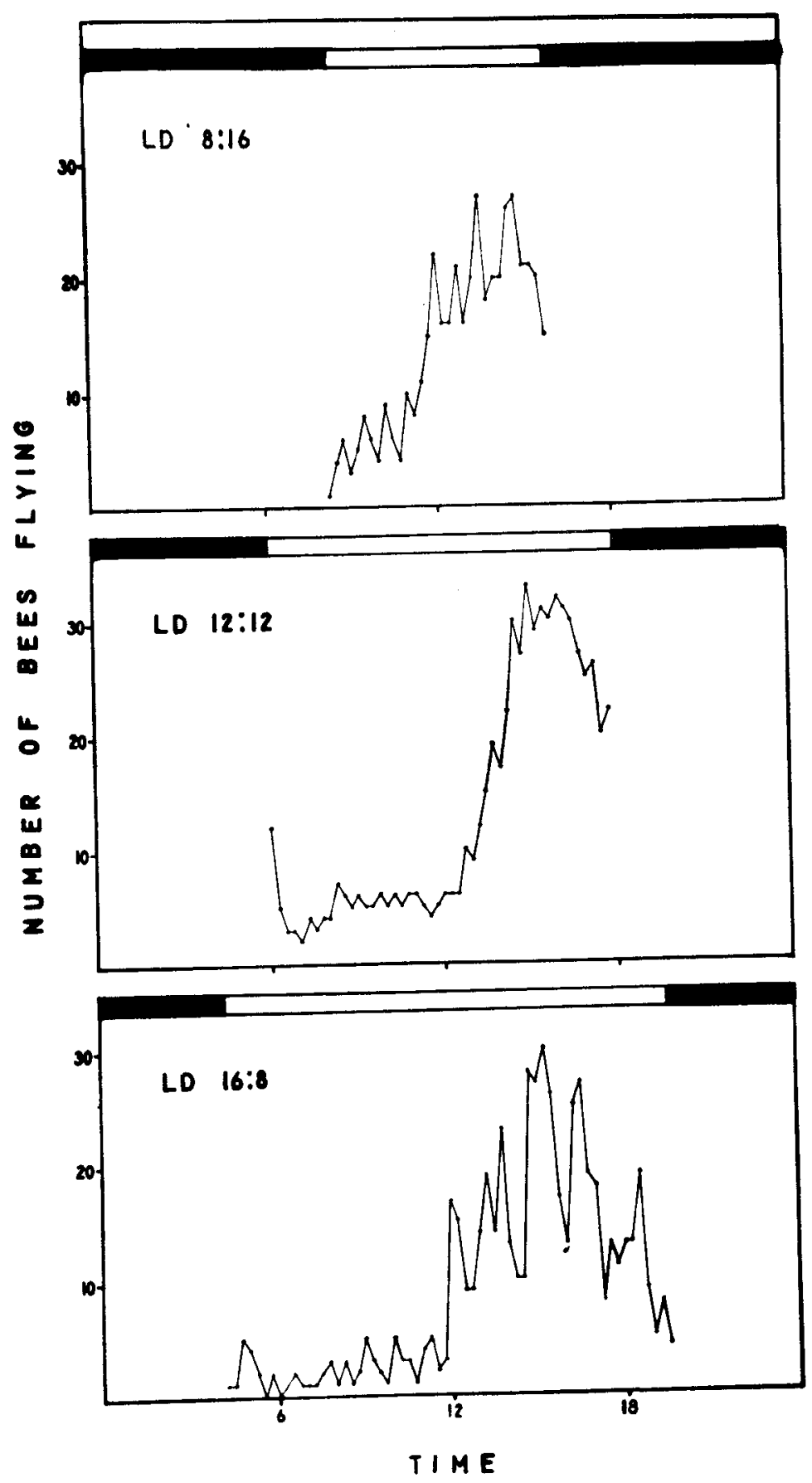

FIG. 2. Diurnal fight patterns of bees exposed to different photophases. Points plotted for LD $8: 16,12: 12$, and $16: 8$ hours are based on averages of 2,8 and 2 counts respectively. 
Fig. 3 shows the results of maintaining colonies in room 1 with continuous light for $5 \frac{1}{2}$ days. The mid-afternoon peak of flight observed during the first day (A) gradually faded until a low rate of nearly constant activity prevailed throughout the day (E). Since there were periods of very low flight activity in the first few days during the period that corresponded with the previous scotophase $(18.00-06.00 \mathrm{hr})$, it apparently took several days for the bees to lose their previous conditioning.

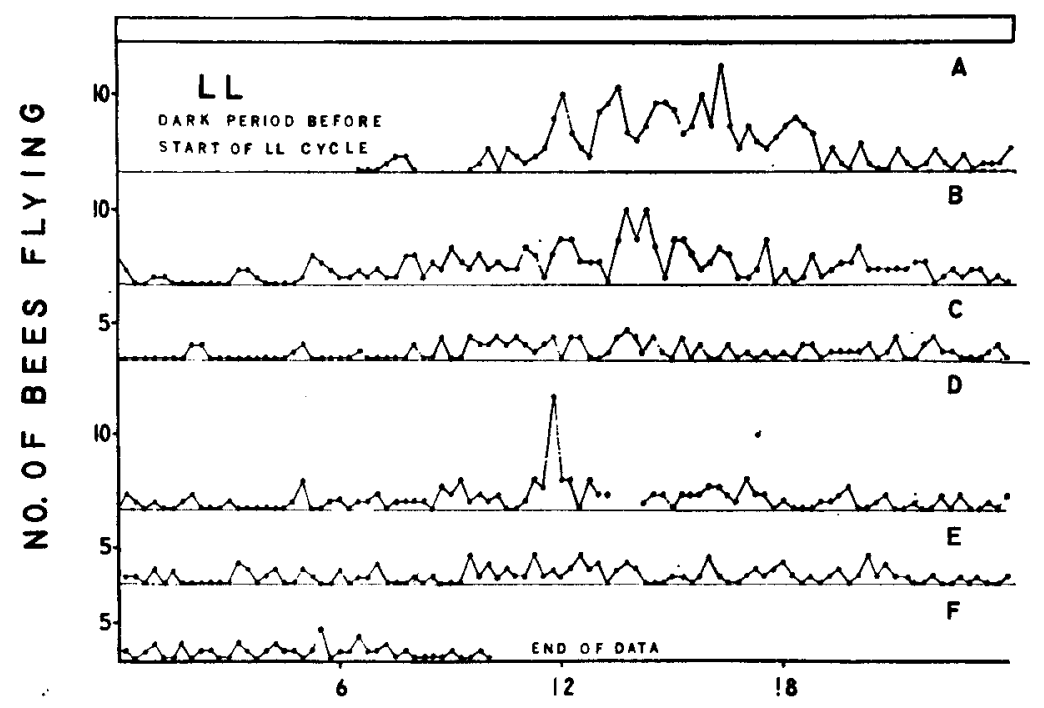

TIME

FIG. 3. Diurnal flight patterns of bees exposed to continuous light for $5 \frac{1}{2}$ days. A-F are consecutive days of the test. The test was preceded by LD $12: 12$, with the photophase between 06.00 and $18.00 \mathrm{hr}$.

Fig. 4A shows the flight pattern of bees in room 2 when they were kept on a LD $12: 12$ hour cycle prior to 8 th December. The colonies were by this time very small, and the flight activity was correspondingly low, which suited the purpose of the subsequent experiment (8th-13th December) on restricting the flight period. (If there had been too many bees it might have been difficult to make accurate counts of the number flying.) There is a noticeable difference between the results shown in Fig. 4A and the corresponding ones in Fig. 2 (LD $12: 12$ ), presumably because the colonies represented in Fig. 4A were smaller. From 8th to 13th December the photophase was reduced to 2 hours per day. On 13th December, after $5 \frac{1}{2}$ days of conditioning to this LD $2: 22$ hour cycle, the maximum flight activity (Fig. 4B, before dotted line) was more than four times as great as that in the preceding LD 12:12 hour cycle (Fig. 4A). The time-lapse photographs showed that flight activity fell off gradually from its peak, and that there was then a sudden drop in the remaining flight $\frac{1}{2} \mathrm{hr}$ before the lights normally went out. On this day the photophase was extended by $2 \frac{1}{2}$ hours, and flight activity continued at a high level but gradually decreased (Fig. 4B, after dotted line).

In 1967 , another test was made to train bees to fly between 04.00 and $06.00 \mathrm{hr}$ by 


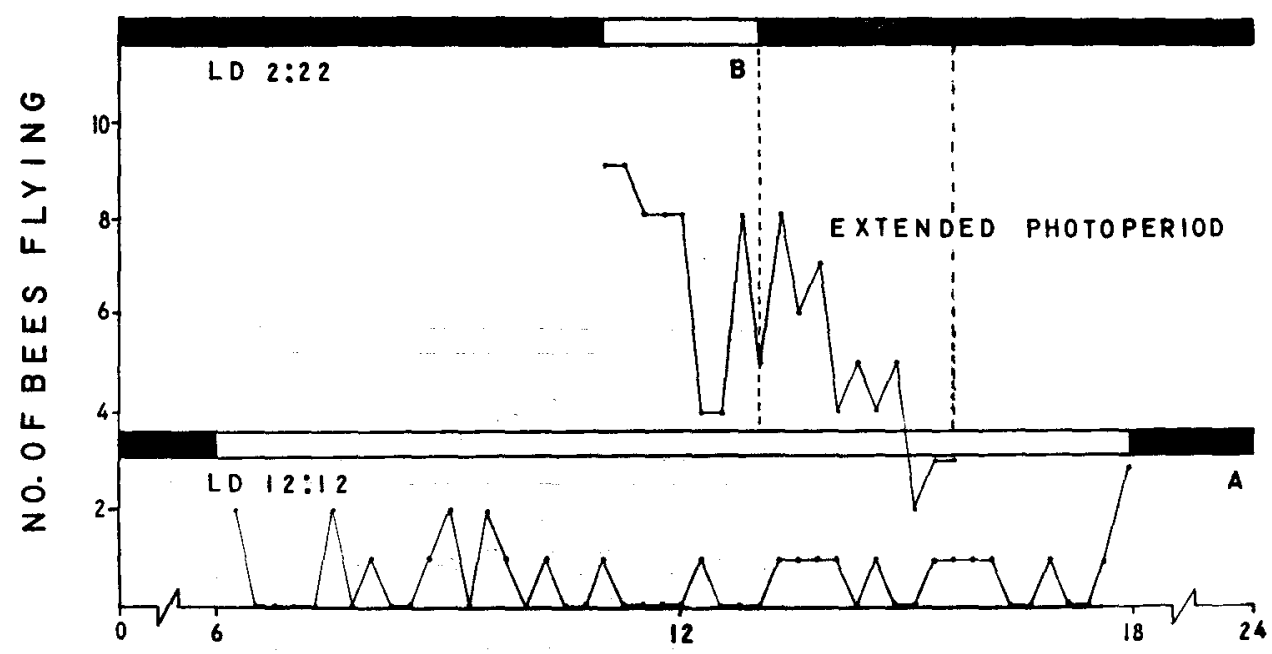

TIME

FIG. 4. Flight pattern (B) after 5 days' exposure to a photoperiod LD $2: 22$; the previous cycle was LD $12: 12$, with the diurnal flight pattern shown below (A). All colonies had low populations, brood rearing had stopped, and few bees were flying. The first dotted line in B shows when the lights normally went out. On the final day (13th December) the photophase was extended by $2 \frac{1}{2} \mathrm{hr}$, i.e. until the second dotted line.

restricting the photophase to those hours (LD $2: 22$ ). After several days of conditioning, the bees flew in large numbers when the lights were on; when the photophase was then extended to 20 hours the flight activity followed a curve similar to that observed in the 1966 test with the LD 2 : 22 cycle. Thus, bees can be conditioned to high flight activity at times other than their "normal" afternoon flight period.

The results confirm other indications that flight rhythms are strongly influenced by light as an exogenous factor. For example, Bennet and Renner (1963) obtained data suggesting that when the lights were out, the photoperiod might set flight rhythms. The decrease in flight activity that we noted (Fig. 3) agrees with their conclusion that flight activity becomes "saltatory" with continuous light. However, Nelson (1964), whose data are generally in accord with the results of the present tests, found that he could superimpose a temperature-correlated rhythm over the daily rhythm.

\section{Conclusions}

Under the conditions of these experiments the following conclusions can be made:

1. As the photophase is lengthened, flight activity per unit time decreases.

2. Bees develop flight patterns in response to cycles of light and dark.

3. Bees can be conditioned to high flight activity at times other than their "normal" peak flight times.

4. Continuous light would seem to provide the best environment for testing biorhythms that are not associated with light and dark periods, since the rhythms of bee flight tend to fade with continuous light. 
Thus, the results of these and earlier investigations suggest that all honeybee castes have a flight rhythm controlled or influenced by photoperiod. In the worker caste, this rhythm is not normally evident because it is overshadowed by exogenous factors such as weather and foraging opportunities. Drone and queen flights are more obviously made in response to photoperiod, because neither caste is engaged in foraging activity.

\section{Acknowledgements}

The authors thank Dr. G. H. Cale of Dadant and Sons for supplying the artificially inseminated queens for these experiments. Special thanks are due to Dr. G. E. Bohart of this Division for his helpful criticism of both the research and this paper.

\section{References}

BennetT, M. F. \& REnNER, M. (1963) The collecting performance of honey bees under laboratory conditions. Biol. Bull., Woods Hole 125(3): 416-430

Butler, C. G. \& Finney, D. J. (1942) The influence of various physical and biological factors of the environment on honeybee activity. An examination of the relationship between activity and solar radiation. J. exp. Biol. 18(3) : 206-212

Domagala-Lipińska, A. (1962) Dzienna dynamika lotu pszczołowatych a temperatura. Ekologia polsk. Ser. B 8(1) : 55-57

GARY, N. E. (1967) Diurnal variations in the intensity of flight activity from honeybee colonies. J. apic. Res. 6(2) : 65-68

Hocking, B. \& Sharplin, C. D. (1964) Bees at 82N. Bee Wld 45(4) : 144-146

Howell, D. D. \& Usinger, R. L. (1933) Observations on the flight and length of life of drone bees. Ann. ent. Soc. Am. 26(2) : 239-246

KenYon, F. C. (1898) The daily and seasonal activity of a hive of bees. Am. Nat. 31(274):90-95

Kurennor, M. N. (1954) On the flight activity and sexual performance of drones. Pchelovodstvo 31(12) : 24-28

Lundie, A. E. (1925) The flight activities of the honeybee. Bull. U.S. Dep. Agric. No. 1328

Nelson, E. (1964) Preliminary observations on the cyclic activity of honey bees in a flight room. Proc. ent. Soc. Manitoba $20: 61-62$

NYE, W. P. (1962) Observations on the behaviour of bees in a controlled-environment room. J. apic. Res. 1 : 28-32

Oertel, E. (1956) Observations on the flight of drone honey bees. Ann. ent. Soc. Am. 49(5) : 497500

Sekiguchi, K. \& Sakagami, S. F. (1966) Structure of foraging population and related problems in the honeybee, with considerations on the division of labour in bee colonies. Rep. Hokkaido natn. agric. Exp. Stn No. 69

Sмттн, F. G. (1953) Beekeeping in the tropics. Bee Wld 34(12) : 233-239

SOCZEK, Z. (1958) [Influence of certain factors on flight and mating in the queen honeybee.] Pszczel. Zesz. Nauk. 2(3) : 109-120

TABER, S., III (1964) Factors influencing the circadian flight rhythm of drone honey bees. Ann. ent. Soc. Am. 57(6) : 769-775 